\title{
Konstrukce identity v kultuře a proti ní: autobiografie Janet Frameové
}

\author{
Zuzana Fonioková
}

\begin{abstract}
Identity Construction within the Culture and against It: Autobiography by Janet Frame

The paper examines a three-volume autobiography (To the Is-Land, An Angel at My Table, and The Envoy from Mirror City) by Janet Frame, focusing on its portrayal of the self-construction of the protagonist. Using a narrative psychological conception of the self (esp. by Dan McAdams) and constructivist theories of autobiographical practices (e.g. Bruner, Eakin), the paper demonstrates the ways in which the depicted search for personal identity in autobiography by Frame interplays with the narrative strategies of the text, and relates this identity search to the cultural determination of self-construction and models of identity available in the given society.
\end{abstract}

\section{KEYWORDS}

Autobiography, identity, narrative, self-concept, Janet Frame.

\section{KLIÍčOVÁ SLOVA}

Autobiografie, identita, narativ, sebepojetí, Janet Frameová.

Tématu osobnosti, osobní identity a psychologického Já (self) se věnuje mnoho př́stupů, a to nejen v psychologii, ale také např. ve filozofii, antropologii nebo sociologii. V této studii se opírám zejména o pojetí vývojové a narativní psychologie, které vidí Já jako psychosociální konstrukt, jehož utváření není nikdy dovršeno, nýbrž probíhá celý život. Identita člověka je v této koncepci nazírána jako zvnitřněný příběh o vlastním životě, který odpovídá na otázku „kdo jsem“. Vytváření osobní identity tematizují i mnohé autobiografie 
a autobiografické psaní je často součástí této konstrukce a významným dějištěm sebereflexe.

Podle Wolfa Wucherpfenniga u autobiografického psaní dochází k souhře pěti vzájemně provázaných prvků: „[...] faktů - konstrukce identity - naratologických schémat - společenských skutečností - psychických potřeb" ${ }^{\text {"WUCHER- }}$ PFENNIG 2009: 272). V této studii budeme interakci jednotlivých faktorů sledovat $\mathrm{v}$ třídílné autobiografii novozélandské spisovatelky Janet Frameové. Zaměříme se na zobrazení utváření osobní identity, a to nejprve s ohledem na to, jak narativní struktura tohoto díla reflektuje znázorněnou konstrukci identity, a poté s ohledem na kulturní determinaci psychologického Já a modely identity dostupné v dané společnosti. Cílem je nastínit několik problémů spojených s konstrukcí osobní identity, jež můžeme v publikovaných autobiografiích pozorovat, a pokusit se o propojení psychologických koncepcí Já s vyprávěcími strategiemi zkoumaného autobiografického textu.

\section{Vrstvy sebereflexe a autobiografický příběh}

Janet Frameová (1924-2004) patří k nejvýznamnějším a nejuznávanějším novozélandským spisovatelům. Je autorkou třinácti románů, mnoha povídek a dvou sbírek básní; velký ohlas vzbudila její autobiografická trilogie: To the Is-Land (1982), An Angel at My Table (1984) a The Envoy from Mirror City (1984) - v roce 1989 všechny tři knihy vyšly znovu v jednom svazku pod názvem $A n$ Autobiography, z něhož je zde citováno. ${ }^{2}$ Frameová zde píše o svém životě od dětství do roku 1963, kdy se po sedmi letech v zahraničí vrátila domů na Nový Zéland. Zásadním milníkem je její hospitalizace v psychiatrické nemocnici (tehdy blázinci) v novozélandském Seacliffu v roce 1945 a následujících devět let, která strávila s přestávkami v různých psychiatrických zařízeních. Čtenár̆ autobiografie se dovídá o událostech, které hospitalizaci předcházely, a dále o životě Frameové po jejím definitivním propuštění; o oněch devíti letech však autobiografie přináší jen málo informací, což autorka zdůvodňuje tím, že už své zážitky z ústavů zpracovala v některých svých románech. Je to jedna z četných připomínek provázanosti jejího života s literaturou.

1) Orig.: [...] „Fakten - Identitätskonstruktion - narratologischen Schemata - gesellschaftlichen Gegebenheiten psychischen Bedürfnissen." Všechny překlady Z. F.

2) V češtině zatím žádné autorčiny texty knižně nevyšly. Na stanici Vltava byly odvysílány jako rozhlasové čtení povídky ze sbírky The Lagoon v překladu Denise Molčanova. Krátké ukázky z několika děl, rovněž v Molčanově překladu, vyšly v literárním časopise Souvislosti 4/2012. 
V prvním díle autobiografie, To the Is-Land, se Frameová věnuje vzpomínkám na dětství. $Z$ hlediska tématu utváření identity se jeví pozoruhodnou pasáž, v níž vypravěčka rekonstruuje svůj dětský postoj k otázce osobnosti: „Člověk musel mít ,osobnost'. Nebyla jsem si vědoma, že bych nějakou měla, i když jsem se chápala různých atributů, které jsem možná měla a možná neměla, a přikrášlovala jsem je“33 (FRAME 1989: 116). Zmiňuje příhodu ze školy, kdy o ní učitelka před tř́idou prohlásila, že je velmi ostýchavá, a Janet ${ }^{4}$ tuto charakteristiku přivítala pro její poetičnost a „udělala jsem ze stydlivosti součást své ,osobnosti “" (IBID.). Je to jeden z případů, kdy Frameová v autobiografii popisuje, jakým způsobem $v$ dětství a mládí tvořila své sebepojetí - do velké míry přejímala názory lidí ve svém okolí.

V tomto kontextu je vhodné zmínit rozlišení dvou aspektů lidské osobnosti, „I“ (čisté Já, čisté ego) a „Me“ (empirické Já, sebepojetí), s nímž poprvé přišel už koncem 19. století William James (JAMES 1892), avšak pracuje s ním i současná psychologie. „“ můžeme popsat jako subjekt a „agens duševního života“, zatímco „Me“ je objekt, „obraz tohoto činného Já“ (BLATNÝ - OSECKÁ - MACEK 1993: 445). Já jako činitel „I“ vytváří tento obraz (empirické Já, „Me“) tak, že mu připisuje vlastnosti, jména, zkušenosti, příběhy apod. (McADAMS 2003). „I“ tudíž vystupuje v roli pozorovatele a „Me“ v roli pozorovaného (McADAMS 2013: 273). Pojem „Já“ (self) tedy zahrnuje jednak aktivní, reflektující instanci („Já přemýšlím“), jednak předmět tohoto reflektování („o sobě“) (OYSERMAN - ELMORE - SMITH 2012: 71). ${ }^{6}$

Tato dualita Já je tedy spjata s procesem sebereflexe. V rámci tohoto procesu vnímáme své skutky, myšlenky, pocity, fenomenální zkušenosti apod. jako své, náležející nám; určujeme sebe jako podmět svého prožívání (McADAMS 1996b: 302): „jsem to ,já', kdo si je vědom sám sebe“ (MACEK 2008: 90). Výsledný agregát přivlastněných položek, ${ }^{7}$ tedy Já jako objekt (Me) neboli sebepojetí, se přitom neustále vyvíjí; sebedefinice není jednorázový, ale průběžný proces.

3) Orig.: „One had to have ,personality‘. I wasn't aware that I had any, although I had seized upon and embellished certain attributes that I may or may not have had."

4) Postavu Frameové v minulosti, tedy hrdinku autobiografie (prožívající Já), budu nazývat Janet, o vyprávějícím Já budu mluvit jako o vypravěčce a k autorce budu odkazovat přímením Frameová. Pozice však místy splývají.

5) Orig.: „made shyness a part of my,personality“.

6) Srov.: „The term self includes both the actor who thinks (,I am thinking') and the object of thinking (,about me')“ (OYSERMAN - ELMORE - SMITH 2012: 71).

7) Tento agregát zahrnuje materiální složku (např. tělo, ale také oblečení, domov nebo třeba auto či zvířecího mazlíčka; James sem řadí rovněž členy rodiny), dále složku sociální (náš obraz v očích druhých, naše pověst apod.) a duchovní (psychické vlastnosti, dispozice a schopnosti, přesvědčení) - JAMES 1892: 176-181. 
Ve zmíněné pasáži u Frameové tedy můžeme sledovat, jak subjekt „I“ připisuje objektu „Me“ vlastnost ostýchavosti. ${ }^{8}$ Zároveň ovšem situaci komplikuje skutečnost, že se o této atribuci dovídáme od vypravěčky, která se na svou minulost dívá z pozice přítomnosti a snaží se své Já minulosti, Já přítomnosti a projektované Já budoucnosti propojit vláknem koherence. Vypravěčka tuto situaci reflektuje: „Pamatuji si a mohu znovu prožít své pocity, ale nyní je v tom, co se tenkrát zdálo tak nevyhnutelné, dychtivost po důvodu“9 (FRAME 1989: 157). V momentě prožívání často jednáme, aniž bychom si uvědomovali širší souvislosti mezi různými událostmi a naším chováním; to, co děláme, nám opravdu připadá jako „nevyhnutelné“ či jako jediná rozumná volba, ale nepřemýšlíme u každého jednotlivého počinu nebo reakce, jaký toto jednání dává smysl v širším kontextu našeho života. Když se však ohlížíme zpět za minulostí a dáváme dohromady svi̊j příběh, nastupuje touha minulé jednání vysvětlovat a hledat v něm obecnější smysl a návaznost na další události. ${ }^{10}$

Autobiografie Frameové podává příběh emancipace $z$ vlivu charakteristik uvalených na Janet druhými lidmi. K atributu ostýchavosti se přidává popis její osoby jako miloučké, bezproblémové dívky („a lovely girl, no trouble at all“) - takto se o ní vyjádřila teta, u níž bydlela. Vypravěčka se této definice ujímá a s drobnými variacemi ji použivá $\mathrm{k}$ popisu chování své mladší verze $\mathrm{v}$ různých situacích. Toto osvojení pohledu zvnějšku literárně stylizovaným způsobem vyjadřuje, že se mladá Janet snažila dostát obrazu sebe samé vytvořenému okolím. S odstupem vypravěčka považuje takové vytváření obrazu druhými, symbolizované použitím gramatické třetí osoby (později v psychiatrické nemocnici půjde dokonce o vynechání osoby a užití trpného rodu), za ničivé pro vlastní identitu. ${ }^{11}$ Přijatá role získala v jejím životě navrch nad subjektivně pocitoovaným jádrem osobnosti.

Vypravěčka popisuje, jakým způsobem po mnoha letech a vskutku děsivých komplikacích (o vlásek unikla lobotomii) došla $\mathrm{k}$ „vlastnictvi““ své identity (srov. FRAME 1989: 282) - tedy jak se oprostila od definic ostatních a začala žít podle svého vlastního sebepojetí. Vylíčení této proměny tvoří základní narativní schéma celé autobiografické trilogie Frameové. Nejvýrazněji toto téma zabarvuje

8) Sociálně kognitivní psychologové však akcentují, že rozlišení Já jako subjektu (I) a Já jako objektu (Me) je možné pouze na teoretické rovině; empiricky jsou tyto aspekty pro svou propojenost neoddělitelné (BLATNÝ 2003: 98).

9) Orig.: „I remember and can relive my feelings but there is now a thirst for reason in what had seemed to be so inevitable."

10) Srov.: „The program of retrieval must be guided by some criteria of relevance, by something like a ,theory' about how the isolated ,facts' of a life cohere" (BRUNER 1993: 45).

11) Srov.: „identity-destroying third person“ (108) a „I became 'she', one of 'them”“ (FRAME 1989: 191). 
druhý díl autobiografie, An Angel at My Table, který pojednává o autorčině adolescenci a mládí, ale vlákno začíná už v prvním díle a pokračuje do posledního, třetího dílu (The Envoy from Mirror City), jenž zobrazuje autorku-třicátnici a léta strávená v zahraničí. Sledujeme zde tedy snahu zařadit velmi rozdílné podoby jedné osoby do souvislého narativu, jenž vysvětlí, jak se ze zakřiknuté dívky žijící v souladu s názory ostatních stala samostatná žena a úspěšná spisovatelka, která žije podle svých vlastních představ. Toto narativní schéma pak určuje, které události jsou do příběhu zařazeny a jakým zpo̊sobem jsou vyprávěny.

$S$ ohledem na vytváření koherence a kontinuity skrz narativ se můžeme pro vysvětlení opět obrátit na psychologii. V návaznosti na rozdělení na „I“ a „Me“ lze psychologické Já označit za vyvíjející se konfiguraci pozorujícího, poznávajícího a konstruujícího subjektu a pozorovaného, poznávaného a konstruovaného objektu. Podle současného amerického vývojového a narativního psychologa Dana P. McAdamse tato konfigurace probíhá na třech rovinách odpovídajících třem složkám Já: Já jako sociální aktér, Já jako motivovaný činitel a Já jako autobiografický autor. ${ }^{12}$ Tři aspekty Já zároveň odpovídají třem různým pozicím, z nichž „I“ reflektuje „Me“ (McADAMS 2013).

Vrstva Já jako sociálního aktéra zahrnuje vlastnosti, společenské role, dovednosti, společenskou pověst a další prvky spojené s působením jedince ve společnosti, které „I“ připisuje „Me“. ${ }^{13}$ Pozice Já jako motivovaného činitele obnáší definování sebe sama skrz osobní cíle, plány, hodnoty, naděje a obavy projektované do budoucnosti. ${ }^{14}$ Vrstva Já jako autobiografického autora odpovídá Já v roli vypravěče příběhů, jehož cílem je vytvoření životního narativu. Sebedefinice se tedy na této rovině uskutečňuje skrz zvnitřněný autobiografický př́iběh, který integruje vzpomínky na minulost s představami o budoucnosti do koherentního a smysluplného celku. S tímto aspektem Já se pojí otázka sebe-kontinuity: jak se z Já minulosti stalo Já př́tomnosti a jak bude vývoj dále pokračovat k Já projektovanému do budoucnosti (McADAMS 2013).

Převezmeme-li stanovisko McAdamse, který zde navazuje na koncept ego identity Erika H. Eriksona, můžeme právě integrační aktivitu na úrovni autobiografického autora považovat za identitu. Pokud lze sebereflexi na úrovni aktéra a činitele shrnout jako odpověd' na otázku „co jsem?“, identita odpovídá

12) Tyto tři vrstvy Já se vyvíjejí postupně (aktér v raném dětství, činitel ve věku od 7 do 9 let a autor ve věku 15 až 25 let); u dospělého jedince jsou zastoupeny a neoddělitelně spjaty všechny tři a dále se vyvíjejí.

13) Tato pozice je spjata se seberegulací (už v raném dětství se skrz zpětnou vazbu okolí učíme, jaké chování je žádoucí a jaké nepřijatelné).

14) Na této rovině se odehrává sebehodnocení s ohledem na schopnost plnit vytyčené cíle a očekávání, které silně ovlivňuje jedincovo sebevědomí. 
na otázku „kdo jsem?“. Odpovědí na první otázku je seznam atributů (vlastností, plánů atd.), které subjekt pocituje jako své; v případě otázky „kdo jsem?“ je potřeba tyto atributy sjednotit tak, aby naše sebepojetí působilo uceleně a smysluplně (McADAMS 1996a: 133-134). Identita je v tomto pojetí prostředek, díky němuž vnímá subjekt „I“ objekt „Me“ jako tentýž např́ic širokým spektrem různých situací a jako kontinuální v čase (McADAMS 2013: 284). ${ }^{15}$

Vrátíme-li se ted' $\mathrm{k}$ výše uvedenému citátu, $\mathrm{v}$ němž Janet přijímá ostýchavost jako součást své osobnosti, vidíme zde dvojí sebereflexi. Jednak můžeme pozorovat sebereflexi postavy-dítěte, která sama sobě připisuje určitou vlastnost jedná se tedy pravděpodobně o autoreflexi na úrovni Já jako sociálního aktéra, na niž se nabaluje introspekce Já jako motivovaného činitele, jelikož protagonistka spojuje své sebepojetí s cílem stát se básnírkou. Toto sebeuvědomování protagonistky je však zahnízděno v sebereflexi vypravěčky, která konstruuje svou identitu převážně na úrovni Já jako autobiografického autora v McAdamsově smyslu, a jde jí tudíž o sjednocení různých manifestací sebe samé v čase do smysluplného kontinua pomocí autobiografického příběhu. Jak již bylo řečeno, tento narativ pomáhá objasnit, jak se z dřívějšího Já stalo Já současné, které je zároveň kompatibilní s budoucím, plánovaným Já. Koherenci příběhu a kontinuitu Já zaručuje mimo jiné právě dějová osnova postupného vymanění se $\mathrm{z}$ područí charakteristik uvalených zvenčí, cesta $\mathrm{z}$ pasivity $\mathrm{k}$ aktivitě. Jakkoli tedy pozorujeme, jak dětská protagonistka vytváři svou osobnost přisvojováním si vlastností, musíme mít zároveň na paměti, že nemusí jít o přesný záznam procesu, jelikož jeho zobrazení se řídí potřebami vyprávějícího Já.

Vliv současné perspektivy je klíčový nejen v oficiálních autobiografiích, ale rovněž ve zvnitřněných sebenarativech. Do těchto příběhů zařazujeme vzpomínky na události ze své minulosti, obsahují ale také plány do budoucna. Dále tvoři jejich součást tzv. „autobiografické uvažování“" (autobiographical reasoning), pomocí nějž své osobní vzpomínky interpretujeme a vyvozujeme z nich závěry o tom, kdo jsme a jaký význam mají naše životy (McADAMS 2013: 279). Jako př́iklad autobiografického uvažování můžeme uvést snahu dopátrat se události, která dala ráz celému dalšímu životu, nebo vypíchnutí určité události jako bodu zvratu. Pod autobiografické uvažování však spadá i spojování epizod do kauzálních sekvencí tak, aby něco vypovídaly o Já - např. tak, aby

15) Tato koncepce tedy vykazuje podobnosti s Ricoerovou dialektikou dvou aspektů identity (idem: týž, stejnost, co jsem; a ipse: já sám, sebe-stálost i přes proměnu v čase, $k d o$ jsem) a jeho pojetím narativní identity, která funguje jako zprostředkovatel mezi těmito dvěma rovinami (RICOEUR 1995). V této studii se však soustředím na poznatky psychologických výzkumů konstrukce Já formou příběhu a osobní identitu jako filozofický problém ponechávám stranou. 
svědčily o celoživotním zápalu pro určitou věc, jenž jedince dovedl do současné situace a směřuje jej $\mathrm{k}$ vytyčenému cíli v budoucnosti (McADAMS 2013: 279). Životní příběhy tedy nevyprávějí jen o tom, co jsme zažili, ale také propůjčují prožitým událostem význam tím, že je umistují do smysluplného kontextu jiných epizod.

(1) Zde je právě velmi zřetelný vliv přítomného okamžiku, v němž sebenarativ konstruujeme, protože $\mathrm{v}$ různých bodech života můžeme mít odlišnou představu o tom, k čemu určité události vedly a dále povedou (tedy jaký mají význam v kontextu životní dráhy) a také které události hrají v našem životě významnou roli. Důležitost hlediska současnosti se odráží jak ve spontánních (ústně vyprávěných) autobiografických příbězích, tak v literárních autobiografiích. Dokládá to i průzkum psychologa Jeroma Brunera, který referuje, že jeho tým ve vzorku obou typů narativů překvapivě nenašel jediný, v němž by bylo více než 70 procent sloves v minulém čase (BRUNER 1991: 70). Poměrně vysoké zastoupení ostatních časů je pochopitelné, když si připomeneme, že životní příběhy odpovídají nejen na otázku, kým jsme byli, ale hlavně kdo jsme. Příběh naší minulosti nám pomáhá vytvářet sebepojetí, zároveň ale naše současné sebepojetí formuje, co a jakým způsobem o sobě vyprávíme.

Psychologové Irena Vlčková a Marek Blatný považují za důvod, proč „jsou autobiografické vzpomínky vždy do jisté míry konstrukcí skutečnosti, respektive minulosti“ právě propojenost s konceptem Já (VLČKOVÁ - BLATNÝ 2005: 184). Základem autobiografických vzpomínek jsou skutečné události, ale interpretované z pozice př́tomnosti, tudíž leckdy upravené pro současné účely vyprávění. Nelze však ztotožňovat autobiografické vzpomínky a životní příběhy neboli sebenarativy. Sebenarativ zahrnuje jen některé vzpomínky a organizuje je spolu s dalšími informacemi (např. plány do budoucna) do časově a tematicky organizovaného celku, jenž tvoří naši identitu (McADAMS 2003: 195).

Významnou úlohu při narativní konstrukci identity tudíž hraje selekce autobiografických vzpomínek. Fungování lidské paměti zajištuuje, že už samotné vzpomínání je selektivní vlivem současných záměrů vzpomínajícího - některé události si jednoduše vůbec nevybavíme. Avšak i mezi vybavenými vzpomínkami si vybíráme ty, které budou spoluvytvářet naše sebepojetí. Vzpomínky tedy třídíme na ty, které vnímáme jako zásadní pro sebedefinici, a ty, které považujeme ve vztahu k našemu Já za bezvýznamné: „Vybíráme události, které považujeme za nejdůležitější pro určení, kdo jsme, a které poskytují našim životům určité zdání jednoty a smyslu, a dodáváme jim symboliku, ponaučení z nich získaná, integrující témata a další osobní významy, jež nám dávají smysl v přítomnosti, 
kdy mapujeme minulost a očekáváme budoucnost“16 (McADAMS 2003: 196). $\mathrm{V}$ tomto smyslu pak můžeme psané autobiografie vnímat jako výběr $\mathrm{z}$ výběru - ze vzpomínek, jež vnímá jako sebedefinující, pisatelka vybírá ty, které odpovídají zvolenému tématu textu, jeho účelu, očekávanému publiku apod.

Značný vliv na konstrukci životního př́iběhu má také samotná narativní forma, jejíž vlastnosti nás navádějí $\mathrm{k}$ určitému způsobu nahlížení na prožité události (narativ například vyžaduje kauzalitu), a způsob, jakým je tato forma používána v dané kultuře (srov. BRUNER 1990). Tento aspekt vystupuje do popředí v psaných autobiografiích, kde se většinou výrazně projevuje potřeba smysluplné návaznosti, logické zápletky, uvěřitelnosti a „vypravovatelnosti“ (jaký příběh stojí za to vyprávět). Jak upozorňuje francouzský filozof Georges Gusdorf, už jen vědomí konce příběhu (,jak to dopadne“, často je to pisatelova současná situace) znemožňuje zobrazit minulost tak, jak se jevila, když ji životopisec prožíval jako přítomnost. Autobiografický narativ připisuje epizodám určitý význam, ačkoli když probíhaly, měly nejspíše významů více, případně tehdy ještě žádný význam nenesly. Přidělený význam pak určuje, které skutečnosti a které jednotlivosti epizod se do vyprávění dostanou, které text zdůrazní a které naopak zcela opomine (GUSDORF 1980: 42). V případě Frameové pozorujeme důraz kladený na ty události a jejich aspekty, které budují zápletku vývoje od pasivity $\mathrm{k}$ aktivnímu přístupu $\mathrm{k}$ vlastnímu životu a identitě. Je to zároveň cesta $\mathrm{k}$ aktérství v rovině jazyka: zatímco $\mathrm{v}$ dětství a mládí se Janet nechala určovat slovy druhých (jako např. „ostýchavá“ nebo „schizofrenie“), v definici sebe samé, k níž se nakonec dopracuje, hraje významnou úlohu její psaní; popisy fascinace některými slovy $\mathrm{v}$ dětství tedy nejsou zařazeny náhodně nebo spontánně, ale slouží zápletce. ${ }^{17}$

16) Orig.: „We choose the events that we consider most important for defining who we are and providing our lives with some semblance of unity and purpose, and we endow them with symbolism, lessons learned, integrative themes, and other personal meanings that make sense to us in the present as we survey the past and anticipate the future."

17) Srov. GUDMUNDSDÓTTIR 2003: 104-107. Frameová při konstrukci svého autobiografického příběhu značně využívá také postupů tradičně spojovaných s fikčním vyprávěním. Jak si všímá Gudmundsdóttirová, už jen skladba jednotlivých dílů, kdy první působí jako úvod, druhý jako vyvrcholení (s klíčovou událostí pobytu v ústavu) a třetí jako epilog, prozrazuje práci s literárními konvencemi (GUDMUNDSDÓTTIR 2003: 102). U spisovatelů v roli životopisce může být snaha o dobrý příběh ještě výraznější než u jiných autobiografů, protože jsou uvyklí praktikovat své řemeslo, tedy psaní fikce. O pokušení vymýšlet si píše např. Mary McCarthyová (McCARTHY 1963: 9); problém vztahu pravdy a fikce se však v autobiografickém psaní literátů objevuje často, a to minimálně od Goetha. 


\section{Kulturní determinace identity}

Každá rekonstrukce vlastního života je nerozlučně spjata s interpretací minulosti, přičemž tato interpretace ovlivňuje nejen způsob zobrazení faktů a událostí, ale také jejich výběr. Výše zmíněná selekce vzpomínek s ohledem na jejich relevanci k sebepojetí ukazuje, jak říká McAdams, že „[d]o určité míry je [...] identita výsledkem volby"18 (McADAMS 2003: 196). Tato volba je však svobodná opravdu jen v omezeném rozsahu, jak se vyjevuje také ve Frameové autobiografii. Mnohé z faktorů, jež ovlivňují konstrukci Já, totiž souvisí s naším životem ve společnosti. Každá kultura nabízí určité modely identity, tedy příklady osobnosti a sebepojetí, které je možno napodobovat (srov. EAKIN 1992: 72). Neznamená to, že by subjektivita nehrála v otázce identity významnou úlohu - ale k vyjádření subjektivity využíváme kulturně určovaných a zprostředkovávaných forem (srov. EAKIN 1992: 88).

Také ve způsobech vyprávění o sobě tak existují rozdíly dané kulturou, v níž jedinec vyrůstá a žije. Jsou to mj. rozdíly v tom, jaké vlastnosti jsou u autobiografického vyprávění preferovány a jaké typy životních příběhů jsou ve společnosti dominantní. Např. současná západní kultura klade při vysvětlování životů důraz na individualitu a autonomii (BRUNER 1993: 44). Významnou roli zde hraje již zmíněná vypravovatelnost příběhů a životů, jejíž kritéria jsou rovněž kulturně determinovaná (srov. McADAMS 2003: 200); seznamujeme se s nimi už v dětství - většinou prostřednictvím rodičů, kteří nás navádějí, jak vyprávět příběhy z každodenního života (EAKIN 2008: 25). Podobně je tomu s představami o tom, co to znamená být člověkem a nejlépe dobrým člověkem, které se liší jednak napřič kulturami a společnostmi, jednak se vyvíjejí s dobou. Životní př́běhy a tím pádem i zásadní složku Já tedy mưžeme spolu s McAdamsem označit za „psychosociální konstrukt“: „[...] v určitém smyslu jsou daná osoba a její definující kultura, příp. kultury, spoluautory životního příběhu. V různých typech kultur dávají smysl různé typy př́iběhư “19 (McADAMS 1996b: 307). Různé kultury mají své vlastní představy o životních příbězích a tím i o tom, jak člověk může nebo by měl chápat sám sebe.

Západní moderní společnost klade ve srovnání s historicky či kulturně odlišnými společenstvími velký důraz na individualismus; jedinec je v ní do menší

18) Orig.: „To a certain degree, then, identity is a product of choice."

19) Orig.: „A life story is a psychosocial construction. [...] Indeed, one can speak of a sense in which the life story is jointly authored by the person and his or her defining culture(s). Different kinds of stories make sense in different kinds of cultures." 
míry určován pevně danými společenskými rolemi. Tato skutečnost zesiluje potřebu definovat sebe sama skrz svůj jedinečný příběh: „[...] autobiografie - zejména v širším významu interpretativní sebe-historie vytvořené daným jedincem, ať už je napsaná či ne - je pro osobní identitu v moderním společenském životě stěžejni“"20 (GIDDENS 2001: 76). Příběh zároveň nutně vychází z kulturně formovaných modelů identity a musí být v dané kultuře interpersonálně srozumitelný. Lidé v moderních společnostech při konstrukci vlastního Já balancují mezi potřebou zdůraznit svou jedinečnost a potřebou integrace do společnosti: „Moderní společnosti výslovně nepředepisují konkrétní identity konkrétním lidem. Současně však tyto společnosti vyžadují, aby byl dospělý člověk někdo, kdo zároveň zapadá a zároveň je jedinečný“"21 (McADAMS 1996b: 306). Tyto požadavky se do značné míry odrážejí také v publikovaných autobiografiích mnoho autorů se snaží svůj život podat jako něčím výjimečný, ale současně také reprezentativní. ${ }^{22}$

Tendence $\mathrm{k}$ jedinečnosti a sounáležitosti jsou patrné i v konstrukci identity, jak je vyobrazena v autobiografii Janet Frameové. Už výše citovaná pasáž promlouvající o tom, že každý musel mít „osobnost“, přináší svědectví o tlaku na individualismus, a to již od dětství. Jedním z klíčových bodů prvního dílu autobiografie je moment, kdy o Janet poprvé někdo řekne, že má fantazii. Frameová cituje svůj dětský deník: „Oni si myslí, že budu učitelkou, ale budu básnírkou“23 (FRAME 1989: 132). Tento moment sebedefinice skrz plány do budoucna nám dává nahlédnout do vypravěččiny představy o vlastní výjimečnosti - i v dalších částech autobiografie se prezentuje jako někdo, kdo žije ve svém jedinečném světě fantazie. Na druhou stranu můžeme velmi dobře pozorovat přání příliš nevyčnívat a strach $\mathrm{z}$ nepřijetí ostatními, který vedl k potlačení vlastních preferencí a životu naplněnému hraním rolí podle představ druhých: „Touha někam patřit zvyšovala mou ochotu nechat ostatní rozhodovat o mém životě “24 (FRAME 1989: 362). Příběh jejího mládí lze číst jako případ přizpůsobení životního

20) Orig.: „[...] autobiography - particularly in the broad sense of an interpretative self-history produced by the individual concerned, whether written down or not - is actually at the core of self-identity in modern social life."

21) Orig.: „Modern societies do not expressly prescribe particular identities for particular adults. At the same time, however, these societies insist that an adult should be someone who both fits in and is unique."

22) Reprezentativnost samotná je přitom také výsledkem kulturní konstrukce. Upozornuuje na to feministická teorie autobiografie, jež si všímá drtivé převahy mužských autorů v autobiografickém kánonu (tj. souboru autobiografických děl, jimž teoretici autobiografie často věnují pozornost) a marginalizace autobiografí́ psaných ženami: reprezentativnost života a možnost exemplárnosti byly po dlouhou dobu vyhrazeny bílým mužům a jejich pozici ve společnosti, Já odpovídající představě maskulinity bylo vnímáno jako univerzální lidské Já (srov. např. ANDERSON 2001: 102-103; FRIEDMAN 1998; JELINEK 1980: 2-10; SMITH 1987).

23) Orig.: „They think I'm going to be a schoolteacher, but I'm going to be a poet.“

24) Orig.: „My desire to belong increased my willingness to allow others to decide my life." 
příběhu externím tlakům. Vypravěčka sama vnímá jako důsledek své submisivnosti a pasivity, že přestala být vlastníkem svého Já (srov. FRAME 1989: 282) - společenské konvence a přesvědčení ostatních zcela upozadily její vlastní sebeurčení.

Být schopen vyprávět vhodný příběh svého života je v západní moderní společnosti normou. Podmínkou úspěšné socializace je osvojení si společensky dohodnutých pravidel vyprávění o sobě, na jejichž základě si vytvoříme soubor příběhů, jimiž se prezentujeme ostatním a do značné míry i sami sobě (EAKIN 2008: 30). Odchylky od očekávaného postupu života je nutné vysvětlit způsobem, který je pro ostatní přijatelný. Porušení těchto pravidel má za následek, že nás ostatní přestanou vnímat jako normální. Podobný scénář popisuje Frameová ve své autobiografii: Janetino neobvyklé chování, pro něž nedodala důvody, mělo za následek diagnózu schizofrenie, mnoho let strávených v psychiatrických ústavech a vnucenou pasivní pozici objektu. Opravdové osvobození od tohoto verdiktu mohlo přijít až po opuštění svazující novozélandské společnosti padesátých let dvacátého století, protože „v konformní společnosti je překvapivě mnoho ,rozhodovačů' o životech a osudech druhých“25 (FRAME 1989: 266). Bez odjezdu do Evropy by se možná nikdy nevyprostila z pasti společenských očekávání.

V Anglii podstoupené psychiatrické vyšetření přineslo zproštující verdikt Frameová nikdy schizofrenií netrpěla a roky v ústavech (včetně elektroléčby) byly zbytečné. Spolu s pravdou o duševním stavu se však vyjevila ještě pozoruhodnější věc: chybná diagnóza do té doby tvořila důležitý konstituující prvek Janetina sebepojetí. Výsledek vyšetření nejdříve přijímá s panikou a pocitem obrovské ztráty. Díky chybně diagnostikované schizofrenii totiž měla k dispozici vysvětlující narativ pro svůj neortodoxní život, pro vybočování z konvencemi určované životní dráhy. ${ }^{26}$ Navíc pro ni duševní nemoc znamenala spojnici k velkým umělcům. Jakkoli tedy na ni byla identita schizofreničky uvalena nedobrovolně, poskytovala jí jisté pohodlí, protože jí dovolovala obhájit svůj způsob života nepřímým poukazem na kulturně uznávaný topos šíleného umělce.

Nešlo přitom jen o narativ vysvětlující její život ostatním lidem, nýbrž také o vlastní sebepojetí - ostatně příběhy, které o sobě vyprávíme druhým, ani nelze od zvnitřněných životních příběhů jasně oddělit a obojí využívá implicitních kulturních modelů. Vypravěčka popisuje, jak si po vyšetření v Anglii uvědomila

25) Orig.: „, [...] in a conformist society there are a surprising number of 'deciders' upon the lives and fate of others [...]"

26) Srov. „How could I explain myself when I could no longer move cunningly but necessarily from the status of a writer to one of having schizophrenia, back and forth when the occasion suited?" (FRAME 1989: 375) 
„Svou existenci na nereálných představách o sobě “, ${ }^{27}$ které podporovali nejen lidé kolem ní, ale rovněž ona sama, a najednou si připadala ochuzena o část sebe samé (FRAME 1989: 383). Odvolání diagnózy ji nutí radikálně přepsat svůj sebenarativ, přijít s novými vysvětleními a znova vystavět koherenci. Nově nabyté poznání nezbytně mění náhled i na minulé události.

Příběhy identity samozřejmě ovlivňují nejen naše vnímání minulosti, ale také naši budoucnost - způsob, jakým sami sebe pojímáme, nutně formuje naše jednání a prožívání. Sebenarativy nejen vyprávíme, ale i žijeme: „narativ napodobuje život, život napodobuje narativ“,28 tvrdí Bruner (BRUNER 2004: 692). Podoba vyprávění o sobě tvaruje i způsob, jakým zakoušíme a prožíváme. Autobiografický příběh, at' už vyslovený či nikoli, může např́ílad člověku uzavřít potenciální životní cesty, protože jeho představa o sobě mu nedovolí si uvědomit možnosti volby (BRUNER 1993: 39). Bruner si dále všímá, že publikované autobiografie často prezentují právě únik z takové autobiografické pasti jako bod zvratu (BRUNER 1993: 39). V případě Frameové sledujeme takovou moc př́iběhu identity v jejím osvojení si role miloučké dívky, kdy ji neschopnost vidět jinou možnost dovedla až k pokusu o sebevraždu. Bodem zvratu je zde hospitalizace. Vyvrácení diagnózy schizofrenie ale představuje další bod zvratu, kdy Janet opouští svůj zavedený způsob vnímání sebe sama (ony „nereálné představy“), což ji nutí přeformulovat svůj životní příběh a otevírá nové možnosti nejen vyprávění, ale také žití. Vypravěčka tento moment interpretuje jako nový začátek a podnět věnovat se naplno spisovatelské dráze. Ztráta identity duševně nemocné osoby, opěrné berličky při vysvětlování sebe sama, ji dovedla ke konstrukci nového sebepojetí, v němž vystupuje v aktivní roli jako tvůrce svého života.

Tato nalezení dřive opomíjených možností dosvědčují Brunerovo mínění, že implicitní narativy vlastního života i explicitně formulované autobiografické příběhy slouží mimo jiné k udržování kulturní stability skrz svou moc omezovat životní možnosti (BRUNER 1993: 39). Jelikož jsou životní příběhy produktem dané kultury, může před námi náš vlastní příběh skrývat určité možnosti, které nejsou obvyklé či kulturně uznávané. $V$ případě hrdinky zkoumané autobiografie to byla volba žít sama, hýčkat si svůj svět imaginace a tvořit literaturu. Tato volba je zároveň volbou vlastního pojetí života a oproštění se od kulturních narativů o tom, jak „správně“ žít, jak trefně vyjadřují slova psychiatra, který Janet

27) Orig.: „[...] my existence on unreal notions of myself.“

28) Orig.: „Narrative imitates life, life imitates narrative.“ 
v jejím novém začátku podpořil: „Doba ,měla bys“ je pryč“29 (FRAME 1989: 384). Janet se rozhodla přestat vysvětlovat svou existenci pomocí narativů vnucených jí druhými a začít aktivně tvořit příběh podle vlastních preferencí.

Konstrukci Já rovněž významně usměrňuje naše př́slušnost $\mathrm{k}$ sociální skupině v rámci dané kultury a další kategorie, vůči nimž zaujímáme pozice, jako jsou pohlaví a gender, společenská třída a ekonomický status, etnický původ, sexuální orientace a další. Tyto a další faktory také výrazně omezují naši svobodnou vůli v roli autobiografického autora, jelikož kulturně přenášené modely osobnosti se liší např. pro ženy a muže nebo pro příslušníky různých tříd. Vzhledem $\mathrm{k}$ tomu, že důležitým cílem životního příběhu je podat život tak, aby byl pro daného jedince přijatelný, hraje velkou roli také to, co v dané kultuře platí za hodnotný život, přičemž očekávání se často liší právě na základě společenských pozic. Je nasnadě, že tyto aspekty nemají vliv pouze na způsoby vyprávění o sobě, ale skrz dominantní narativy i na životní volby a vnímání zkušeností.

Pokud naše zkušenosti a dosavadní průběh života neodpovídají společensky dominantním příběhům (master narativům), snažíme se „najít význam mimo běžně dostupné zápletky“30 (ANDREWS 2004: 1). Autobiografická vypravěčka zkoumaného textu reflektuje své odchýlení od dominantního narativu života ženy své doby v souvislosti se svým těžkým „novým začátkem“ po vyvrácení domněnky, že je duševně nemocná: „Vím, že v mém tehdejším věku, po třicítce, by se většině žen dostalo pomoci od druha, manžela, společníka. Vím také, že neexistuje žádná ,většina žen' a že nebýt jednou z nich, z důvodu nechuti nebo dokonce nezpůsobilosti, by nemělo být osobním selháním: selhání spočívá v očekáváních ostatních“31 (FRAME 1989: 390-391). Tento výrok svědčí o emancipaci z kulturně konstruované normality, ze společenských požadavků na řádný život: nejen že se rozhodla žít sama, nebot̉ jí to tak vyhovuje, ale také vědomě odmítá tuto alternativu považovat za méněcennou jen proto, že neodpovídá standardním předpokladům vydařeného života. Odmítá reprodukovat kulturně dominantní příběhy hodnotného a smysluplného života a vytváří proti-narativ, který částečně reflektuje její dosavadní život a částečně projektuje budoucnost: příběhy napodobují život, život napodobuje příběhy.

29) Orig.: „The ,you should' days were over.“

30) Orig.: „The challenge then becomes one of finding meaning outside of the emplotments which are ordinarily available."

31) Orig.: „I know that at my age then, in my early thirties, most women would have the help of a mate, husband, companion. I know also that there are no 'most women' and not to be one, through disinclination or disability even is not to be a personal failure: the failure lies in the expectations of others." 
Jak jsme ukázali, současné teorie naznačují, že psychologické Já je do velké míry tvořeno společností, $v$ níž jedinec žije; individuum a kulturu nelze oddělit, protože i percepce je kulturně determinovaná a naše zkušenost je tak vždy již kulturou nasáklá. Psané autobiografie pak můžeme spolu s Eakinem chápat jako „konstrukt konstruktu“ - jako (re)konstrukci snahy vyjádřit svou subjektivitu pomocí kulturně uznávaných vzorců (EAKIN 1992: 102-103). Některé autobiografické texty reflektují potýkání se s kulturně determinovanými modely identity explicitněji než jiné - domnívám se, že jedním z nich je také autobiografie Janet Frameové, jež přináší fascinující příběh trnité cesty za takovým sebepojetím, které zobrazenému subjektu umožnilo úspěšný život ve společnosti bez pocitu odcizení.

\section{PRAMENY}

FRAME, Janet 1989 [1982, 1984, 1984] An Autobiography (Auckland: Century Hutchinson)

McCARTHY, Mary

1963 [1957] Memories of a Catholic Girlhood (Harmondsworth: Penguin)

\section{LITERATURA}

ANDERSON, Linda

2001 Autobiography (London: Routledge)

\section{ANDREWS, Molly}

2004 „Counter-Narratives and the Power to Oppose“, in Michael Bamberg, Molly Andrews (eds.): Considering Counter-Narratives. Narrating, Resisting, Making Sense (Amsterdam: John Benjamins Publishing Company), s. 1-6

\section{BLATNÝ, Marek}

2003 „Sebepojetí z pohledu sociálně-kognitivní psychologie“, in Marek Blatný, Alena Plháková (eds.): Temperament, inteligence, sebepojetí. Nové pohledy na tradiční témata psychologického výzkumu (Brno: Psychologický ústav Akademie věd ČR), s. 87-141

\section{BLATNÝ, Marek - OSECKÁ, Lída - MACEK, Petr}

1993 „Sebepojetí v současné kognitivní a sociální psychologii“, Československá psychologie 37, č. 5, s. 444454 
Zuzana Fonioková

Konstrukce identity v kultuře a proti ní: autobiografie Janet Frameové

BRUNER, Jerome

1990 Acts of Meaning: Four Lectures on Mind and Culture (London: Harvard University Press)

1991 „Self-Making and World-Making“, Journal of Aesthetic Education 25, č. 1, s. 67-78.

1993 „The Autobiographical Process“, in Robert Folkenflik (ed.): The Culture of Autobiography: Constructions of Self-representation (Stanford: Stanford University Press), s. 38-56

2004 [1987] „Life as Narrative“, Social Research 71, č. 3, s. 691-710

\section{EAKIN, Paul John}

1992 Touching the World. Reference in Autobiography (Princeton: Princeton University Press)

2008 Living Autobiographically. How We Create Identity in Narrative (London: Cornell University Press)

FRIEDMAN, Susan Stanford

1988 „Women's Autobiographical Selves. Theory and Practice“, in Shari Benstock (ed.): The Private Self. Theory and Practice of Women's Autobiographical Writings (London: Universit of North Carolina Press), s. 34-62

GIDDENS, Anthony

1991 Modernity and Self-Identity (Cambridge: Polity Press)

GUDMUNDSDÓTTIR, Gunnthórunn

2003 Borderlines. Autobiography and Fiction in Postmodern Life Writing (Amsterdam: Rodopi)

\section{GUSDORF, Georges}

1980 [1956] „Conditions and Limits of Autobiography“, přel. James Olney, in James Olney (ed.): Autobiography: Essays Theoretical and Critical (Princeton: Princeton University Press), s. 28-48

JAMES, William

1892 Psychology (New York: Henry Holt)

JELINEK, Estelle C.

1980 „Introduction“, in Estelle C. Jelinek (ed.): Women's Autobiography: Essays in Criticism (Bloomington: Indiana University Press), s. 1-20

MACEK, Petr

2008 „Sebesystém, vztah k vlastnímu já“, in Jozef Výrost, Ivan Slaměník (eds.): Sociální psychologie (Praha: Grada, 2. vyd.), s. 89-107

McADAMS, Dan P.

1996a „Narrating the Self in Adulthood“, in Gary Kenyon, James E. Birren, Jan-Erik Ruth, Johannes J. F. Schroots, Torbjorn Svensson (eds.): Aging and Biography: Explorations in Adult Development (New York: Springer), s. 131-148

1996b „Personality, Modernity, and the Storied Self: A Contemporary Framework for Studying Persons“, Psychological Inquiry 7, č. 4, s. 295-321

2003 „Identity and the Life Story“, in Robyn Fivush, Catherine A. Haden (eds.): Autobiographical memory and the construction of a narrative self: developmental and cultural perspectives (London: Lawrence Erlbaum), s. 187-208. 
2013 „The Psychological Self as Actor, Agent, and Author“, Perspectives on Psychological Science 8, č. 3, s. 272-295

OYSERMAN Daphna, Kristen ELMORE, George SMITH

2012 „Self, Self-concept, and Identity“, in Mark R. Leary, June Price Tangney (eds.): Handbook of Self and Identity, 2. vyd. (New York: The Guilford Press), s. 69-104

RICOEUR, Paul

1995 Oneself as Another, přel. Kathleen Blamey (Chicago: The University of Chicago Press)

SMITH, Sidonie

1987 A Poetics of Women's Autobiography. Marginality and the Fictions of Self-Representation (Bloomington/ Indianapolis: Indiana University Press)

VLČKOVÁ, Irena a Marek BLATNÝ

2005 „K narativnímu pojetí autobiografické paměti: výzkumné možnosti metody čáry života“, in Kvalitativní prístup a metody ve vědách o člověku IV (Olomouc: Univerzita Palackého v Olomouci), s. 183-199

WUCHERPFENNIG, Wolf

2009 „Autobiographisches Schreiben und Identitätsarbeit. 10 Thesen“, in Michael Grote, Beatrice Sandberg (edd.): Autobiographisches Schreiben in der deutschsprachigen Gegenwartsliteratur: Entwicklungen, Kontexte, Grenzgänge (München: IUDICIUM Verlag), s. 272-279

Mgr. Zuzana Fonioková, Ph.D., foniokov@phil.muni.cz, Ústav české literatury a knihovnictví, Filozofická fakulta Masarykovy univerzity, Brno, Česká republika I Department of Czech Literature, Faculty of Arts, Masaryk University, Brno, Czech Republic 